\title{
INCREASING TEACHERS' CAPABILITIES IN ONLINE LEARNING BY USING WHATSAPP DURING THE PANDEMIC AT SDN 18 BENGKALIS
}

\author{
Kamaruddin \\ SDN 18 Bengkalis, Indonesia \\ kamaruddinrpt@gmail.com
}

\begin{abstract}
Organizing online learning for each educational unit and developing or determining how to provide learning to students could be done by using social media. Choosing social media in carrying out learning is necessary because social media did not recognize space and time, it made it easier to communicate with people who were far apart. Thus, it was necessary to train teachers in using WhatsApp as an alternative to learning by using action research methods or often school action research. This research involved 8 teachers at SDN 18 Bengkalis. The results of the study found that the teachers' understanding in online learning in Cycle I was 51.13 with sufficient category. After making improvements and seeing reflections from learning, it was continued with cycle II with the results obtained an average of 73.13 with good category while the teacher's ability in learning in cycle I got sufficient category. In cycle II, out of 8 teachers, 2 teachers got very good category and 6 people got good category. In the learning carried out by the teacher using WhatsApp, there was an increase compared to cycle I. In cycle II, the teachers were already able to use WhatsApp in explaining, providing guidance, and also providing tasks that would be done by the teacher.
\end{abstract}

Keywords: teachers' ability, online learning

\section{PENINGKATAN KEMAMPUAN GURU DALAM PEMBELAJARAN DARING DENGAN MENGGUNAKAN WHATSAPP PADA MASA PANDEMIK DI SDN 18 BENGKALIS}

\begin{abstract}
ABSTRAK
Menyelenggarakan pembelajaran daring setiap satuan pendidikan mengembangkan atau menentukan bagaimana cara memberikan pembelajaran kepada peserta didik salah satunya dengan menggunakan media sosial, dipilihnya media sosial dalam melaksanakan pembelajaran dikarena media sosial tidak mengenal ruang dan waktu, memudahkan berkomunikasi dengan orang yang berjauhan. Sehingga perlu pelatihan kepada guru dalam menggunakan WhatsApp sebagai alternatif pembelajaran dengan menggunakan metode penelitian Tindakan atau sering juga penelitian Tindakan sekolah dengan subjek penelitian 8 orang guru di SDN 18 Bengkalis. Hasil penelitian tentang pemahaman guru dalam pembelajaran daring pada sikus I dengan ratarata kemampuan guru sebesar 51.13 dengan kategori cukup. Setelah dilakukan perbaikan dan melihat refleksi dari pembelajaran maka dilanjutkan dengan siklus II dengan hasil yang diperoleh rata-rata 73.13 dengan kategori baik pemahaman guru dalam pembelajaran daring dengan menggunakan WhatsApp sedangkan pada kemampuan guru dalam pembelajaran pada siklus I dari 8 orang guru mendapatkan kategori cukup. Pada siklus II dari 8 orang guru terlihat 2 orang yang memperoleh kategori sangat baik, dan 6 orang yang mendapatkan kategori baik. Dalam pembelajaran yang dilakukan guru dengan menggunakan WhatsApp sudah mengalami peningkatan dibandingkan pada siklus I. Guru pada siklus II ini sudah mampu menggunakan WhatsApp dalam menjelaskan, memberikan bimbingan, dan juga memberikan tugas-tugas yang akan dikerjakan guru.
\end{abstract}

Kata Kunci: kemampuan guru, pembelajaran daring

\begin{tabular}{|c|c|c|}
\hline Submitted & Accepted & Published \\
\hline 17 Juni 2021 & 09 September 2021 & 17 September 2021 \\
\hline
\end{tabular}

\begin{tabular}{|l|l|l|l|}
\hline Citation & $:$ & Kamaruddin, K. (2021). Increasing Teachers' Capabilities in Online Learning by Using Whatsapp during the Pandemic at \\
& & $\begin{array}{l}\text { SDN } 18 \text { Bengkalis. Jurnal PAJAR (Pendidikan dan Pengajaran), 5(5), 1490-1496. DOI : } \\
\text { http://dx.doi.org/10.33578/pjr.v5i5.8521. }\end{array}$ \\
\hline
\end{tabular}

\section{PENDAHULUAN}

Pada saat ini masayarakat global yang saat ini sedang dilanda pandemi covid-19 (coronavirus disease that was discovered in 2019) artinya penyakit ini ditemukan pada 2019 dan sudah menyebar hampir keseluruh negeri. Virus ini mudah sekali tertular kepada siapa saja, termasuk anak-anak. Penularan yang begitu cepat dan masif pemerintah mengeluarkan kebijakan seperti social ditancing, physical distancing, hingga pemberlakuan pembatasan kegiatan masyarakat (PPKM). Kondisi seperti ini membuat masyarakat harus melakukan aktifitasnya dirumah saja. Tentu 
hal ini juga akan berdampak pada kegitan belajar mengajar yang harus menghentiakn proses pembelajaran secara tatap muka. Sebagai gantinya tentu proses pembelajaran dilakukan dengan cara daring yang bisa dilaksanakan dari rumah masingmasing siswa. Menyikapi dengan permasalahan penyebaran covid-19 Pemerintah telah berupaya mengantisipasi penyebaran covid-19 dilingkungan pendidikan melalui Sesuai dengan Surat Edaran Mendikbud Nomor 4 tahun 2020 tentang pelaksanaan kebijakan pendidikan dalam masa darurat penyebaran corona virus disease (COVID19) menganjurkan untuk melaksanakan proses belajar dari rumah melalui pembelajaran daring.

Dalam menyelenggarakan pembelajaran daring setiap satuan pendidikan mengembangkan atau menentukan bagaimana cara memberikan pembelajaran kepada peserta didik salah satunya dengan menggunakan media sosial, dipilihnya media sosial dalam melaksanakan pembelajaran dikarena media sosial tidak mengenal ruang dan waktu, memudahkan berkomunikasi dengan orang yang berjauhan (Sahidillah \& Miftahurrisqi, 2019). Selain itu, dengan perkembangan teknologi khususnya internet yang sangat pesat menjadikan manusia lebih mudah dalam melakukan aktivitas termasuk dalam aspek komunikasi muncul cara berkomunikasi baru di masyarakat, salah satunya dengan menggunkan media sosial, seperti: FB, instagram, telegram, path, whatsaap, dan lain-lain. Media sosial merubah paradigma berkomunikasi di masyarakat saat ini, melalui media sosial komunikasi menjadi tak terbatas jarak, waktu, dan ruang bisa terjadi dimana saja, tanpa harus tatap muka (Watie, 2011).

Tentu hal ini memerlukan kesiapan dari berbagai pihak untuk melaksanakan pembelajaran secara daring. Pelaksanaan proses pembelajaran daring memerlukan perangkat pendukung seperti komputer, laptop, atau HP, dan juga tentu jaringan koneksi internet yang terhubung secara baik. Pada tataran pelaksanaanya pembelajaran daring memerlukan dukungan perangkatperangkat mobile seperti smarphone atau telepon adroid, laptop, komputer, tablet, dan iphone yang dapat dipergunakan untuk mengakses informasi kapan saja dan dimana saja (Gikas \& Grant, 2013).
Sistem Pembelajaran daring (dalam jaringan) merupakan sistem pembelajaran tanpa tatap muka secara langsung antara guru dan siswa tetapi dilakukan melalui online yang menggunakan jaringan internet (Ruskan,etc 454:2012). Basori (2017:42) menyatakan bahwa Pembelajaran Daring adalah pembelajaran yang menggunakan peratalatan elektronik jaringan (LAN, WAN, atau internet) untuk menyampaikan materi pembelajaran, interaksi, maupun bimbingan. Menurut Moore, Dickson-Deane, \& Galyen (2011) Pembelajaran daring merupakan pembelajaran yang menggunakan jaringan internet dengan aksesibilitas, konektivitas, fleksibilitas, dan kemampuan untuk memunculkan berbagai jenis interaksi pembelajaran.

Penggunaan beberapa aplikasi pada pembelajaran daring sangat membantu guru dalam proses pembelajaran ini (Hamid, 2015:32). Menurut Jumiatmoko (2016) mengatakan bahwa WhatsApp merupakan aplikasi berbasis internet yang memungkinkan setiap penggunanya dapat saling berbagi berbagai macam konten sesuai dengan fitur pendukungnya. Whatsapp adalah salah satu aplikasi yang digunakan sebagai media pembelajaran pada saat pandemi covid-19 yang bertujuan untuk membantu guru dan siswa dalam kegiatan belajar mengajar yang pada saat ini kegiatan belajar mengajar tidak bisa dilakukan dengan tatap muka dikarenakan pandemi covid19.

Melakukan pembelajaran menggunakan whatsapp diharapkan tujuan pembelajaran pada masa pandemi covid-19 ini akan lebih mudah direalisasikan dan sarat kebermaknaan. Oleh karena itu, penggunaan whatsapp ini sesungguhnya mempermudah guru dalam megelola pembelajaran dan mnyampaikan informasi secara tepat dan akurat kepada peserta didik pada saat pembelajaran dilakukan dengan jarak jauh dalam jaringan (daring). Umumnya para pengguna WA menyebutkan alasan memilih aplikasi ini adalah karena tersedianya berbagai kemudahan yang ada didalamnya disamping tidak mengeluarkan biaya alias gratis (Pranajaya \& Hendra Wicaksono, 2017). Dengan demikian, pembelajaran daring sebagai solusi yang efektif dalam pembelajaran di rumah guna memutus mata 
rantai penyebaran Covid-19, physical distancing (menjaga jarak aman) juga menjadi pertimbangan dipilihnya pembelajaran tersebut. Kerjasama yang baik antara guru, siswa, orangtua siswa dan pihak sekolah menjadi faktor penentu agar pembelajaran daring lebih efektif. Untuk itu peneliti tertarik melakukan penelitian tentang pemahaman Guru dalam pembelajaran Daring.

\section{METODE PENELITIAN}

Jenis Penelitian ini adalah Penelitian Tindakan (action research). Penelitian yang dilakukan adalah penelitian kuantitatif yaitu penelitian yang menjelaskan upaya-upaya yang dilakukan untuk meningkatkan kemampuan guru dalam melaksanakan pembelajaran daring melalui aplikasi WhatsApp pada proses belajar mengajar. Penelitian ini akan dilaksanakan di SD Negeri 18 Bengkalis Tahun Ajaran 2020/2021 pada bulan Januari sampai dengan April 2021. Subjek dalam penelitian ini adalah seluruh Guru di SD Negeri 18 Bengkalis yang berjumlah 10 orang Guru, berdasarkan hasil observasi, guru-guru tersebut belum maksimal dalam melaksanakan pembelajaran Daring melalui Aplikasi WhatsApp. Objek penelitian ini adalah sebagai upaya meningkatkan kemampuan Guru dalam pembelajaran Daring melalui Aplikasi WhatsApp Penelitian ini dilaksanakan selama 2 siklus (Arikunto, 2006:16) yaitu Siklus I dan II Pada Siklus I dilaksanakan kegiatan pembelajaran Daring dan pada siklus ke II dilaksanakan kegiatan pembelajaran Daring dari hasil perbaikan pada siklus I. Hasil refleksi siklus I digunakan sebagai acuan dalam menentukan perbaikan tindakan pada siklus II Sedangkan pada refleksi II digunakan sebagai acuan untuk rencana tindak lanjut pembelajaran Daring selanjutnya. Tindakan dilakukan secara bertahap yaitu ; siklus I dilakukan menggunakan secara kelompok, kemudian siklus II dilakukan secara individual yang terdiri dari tahap perencanaan, pelaksanaan tindakan, pengamatan/observasi dan refleksi. Data awal penelitian ini adalah berupa hasil pengamatan secara rutin dari peneliti sebagai Kepala Sekolah, serta data akhir diperoleh melalui observasi, dokumentasi dan pengisian lembar instrumen penelitian.

Analisis data yang digunakan peneliti dengan menggunakan analisis deskriptif komparatif, yaitu dengan membandingkan pelaksanaan pembelajaran Daring. Selanjutnya dari hasil nilai kemampuan melaksanaan pembelajaran Daring dibandingkan dengan hasil sesudah dilaksanakan pelatihan untuk mengetahui kemajuan hasil yang dicapai dalam tampilan kemampuan kinerja guru di kelasnya.

\section{HASIL DAN PEMBAHASAN}

Penelitian tindakan yang dilakukan di SD Negeri 8 Bengkalis ini dilakukan oleh kepala sekolah melalui tehnik supervisi akademik secara berkelompok sebagai upaya untuk meningkatkan kemampuan/kompetensi guru dalam pelaksanaan pembelajaran Daring di kelas. Penelitian dilakukan terhadap 8 orang guru, permasalahan dalam penelitian tindakan ini difokuskan pada peningkatan kompetensi guru dalam pembelajaran Daring dengan asumsi apabila guru sudah mampu melaksanakan dengan baik, maka setidaknya sudah memiliki pedoman untuk melakukan langkahlangkah kegiatan pembelajaran Daring di kelas sesuai dengan mata pelajaran masing-masing. Kegiatan yang dilakukan dalam 2 siklus ini, dilakukan sejak bulan Juli sampai bulan September dengan menitikberatkan pada unsur-unsur dan langkah-langkah penyusunan pembelajaran Daring sebagaimana yang terlihat pada kegiatan tindakan penelitian yang telah diuraikan.

Tabel 1. Pemahaman Guru dalam Pembelajaran Daring Pada Siklus I dan II

\begin{tabular}{lllc}
\hline No & Nama & Siklus I & Sikulus II \\
\hline 1 & Guru 1 & 37 & 56 \\
2 & Guru 2 & 56 & 79 \\
3 & Guru 3 & 40 & 65 \\
4 & Guru 4 & 59 & 81 \\
5 & Guru 5 & 70 & 84 \\
6 & Guru 6 & 45 & 65
\end{tabular}




\begin{tabular}{llcc}
$7 \quad$ Guru 7 & 35 & 70 \\
$8 \quad$ Guru 8 & 67 & 85 \\
Rata-rata & $\mathbf{5 1 . 1 3}$ & $\mathbf{7 3 . 1 3}$ \\
Kategori & Cukup & Baik \\
\hline
\end{tabular}

Sesuai dengan tabel 1 tentang pemahaman guru dalam pembelajaran daring pada sikus I dengan rata-rata kemampuan guru sebesar 51.13 dengan kategori cukup. Setelah dilakukan perbaikan dan melihat refleksi dari pembelajaran maka dilanjutkan dengan siklus II dengan hasil yang diperoleh rata-rata 73.13 dengan kategori baik pemahaman guru dalam pembelajaran daring dengan menggunakan WhatsApp. Untuk lebih jelasnya akan digunakan grafik yang akan terlihat pada gambar 1 .

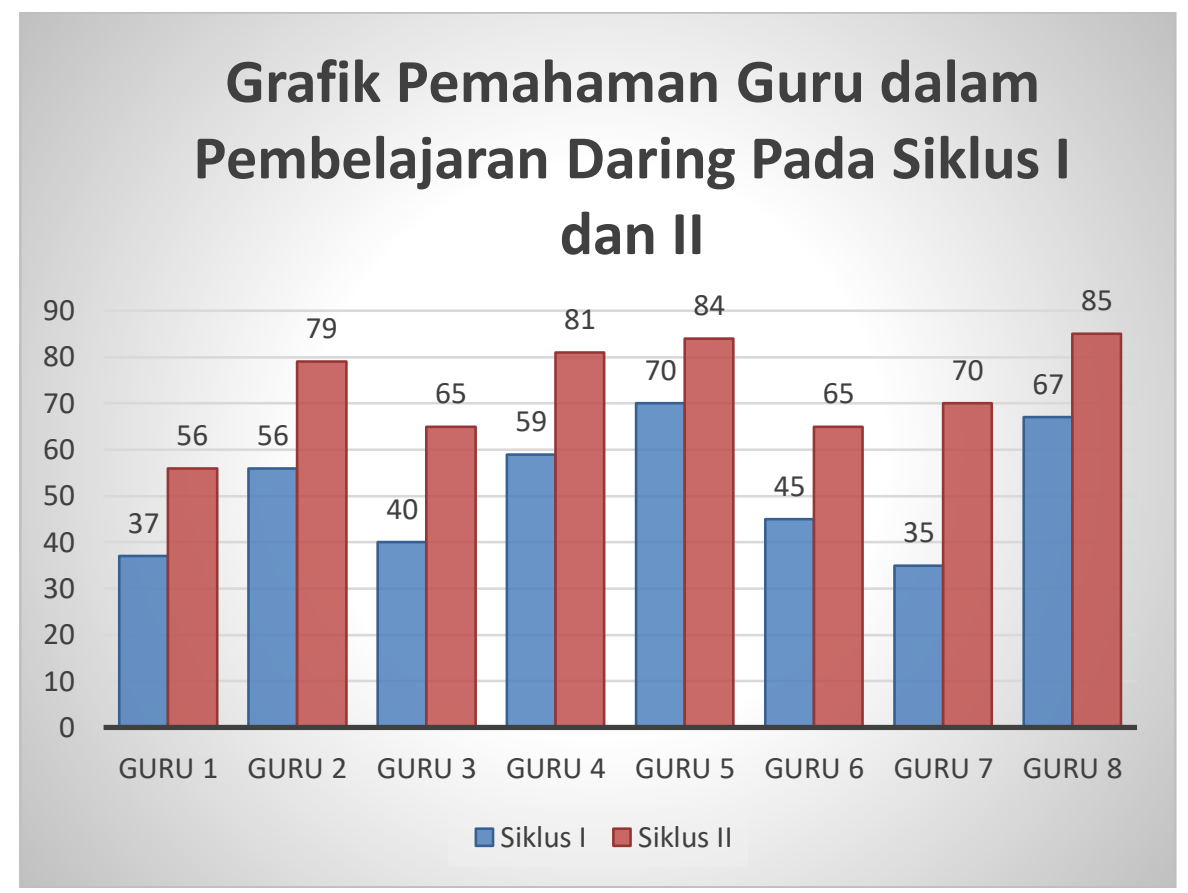

Gambar 1. Grafik Pemahaman Guru Siklus I dan Siklus II

Berdasarkan hasil penelitian di siklus I tentang pemahaman guru dalam pembelajaran Daring yang dilakukan selama proses pembelajaran di SDN 18 Bengkalis didapat 4 orang Guru memiliki pemahaman pembelajaran daring dalam kategori Kurang Baik, 5 orang Guru memiliki pemahaman pembelajaran daring dalam kategori Cukup Baik, 3 orang Guru memiliki pemahaman pembelajaran daring dalam kategori Baik, dan 3 orang Guru memiliki pemahaman pembelajaran daring dalam kategori Baik.
Hasil penelitian di siklus II tentang pemahaman guru dalam pembelajaran Daring yang dilakukan selama proses pembelajaran di SDN 18 Bengkalis didapat 4 orang Guru memiliki pemahaman pembelajaran daring dalam kategori Cukup Baik, 8 orang Guru memiliki pemahaman pembelajaran daring dalam kategori Baik, dan 3 orang Guru memiliki pemahaman pembelajaran daring dalam kategori Sangat Baik. 
Tabel 2. Kemampuan Guru dalam Pembelajaran Daring dengan Menggunakan WhatsApp Siklus I

\begin{tabular}{|c|l|c|c|c|c|c|c|c|c|}
\hline No. & Kategori & Guru & $\mathbf{G u r u}$ & $\mathbf{G u r u}$ & $\mathbf{G u r u}$ & $\mathbf{G u r u}$ & $\mathbf{G u r u}$ & $\mathbf{G u r u}$ & $\mathbf{G u r u}$ \\
\hline 1 & $\begin{array}{l}\text { Guru mampu membuka } \\
\text { pembelajaran dengan } \\
\text { menggunakan WhattApp }\end{array}$ & 52 & 62 & 35 & 50 & 45 & 50 & 44 & 65 \\
\hline 2 & $\begin{array}{l}\text { Guru mampu mengirim } \\
\text { meteri yang akan } \\
\text { disampaikan melalui } \\
\text { WhatssApp }\end{array}$ & 60 & 50 & 40 & 35 & 56 & 42 & 57 & 40 \\
\hline 3 & $\begin{array}{l}\text { Guru mampu menjelaskan } \\
\text { meteri yang disampaikan } \\
\text { melalui WhatssApp }\end{array}$ & 45 & 47 & 60 & 55 & 35 & 40 & 40 & 45 \\
\hline 4 & $\begin{array}{l}\text { Guru mampu membimbing } \\
\text { diskusi di whatssApp }\end{array}$ & 30 & 62 & 40 & 40 & 55 & 60 & 55 & 50 \\
\hline 5 & $\begin{array}{l}\text { Guru mampu menutup } \\
\text { pembelajaran dengan } \\
\text { menggunakan WhattApp }\end{array}$ & 50 & 45 & 55 & 45 & 64 & 55 & 60 & 46 \\
\hline 6 & Rata-rata & 47.4 & 53.2 & 46 & 45 & 51 & 49.4 & 51.2 & 49.2 \\
\hline 7 & Kategori & $\mathrm{C}$ & $\mathrm{C}$ & $\mathrm{C}$ & $\mathrm{C}$ & $\mathrm{C}$ & $\mathrm{C}$ & $\mathrm{C}$ & $\mathrm{C}$ \\
\hline
\end{tabular}

Berdasarkan tabel 2 kemampuan guru dalam pembelajaran daring dengan menggunakan WhatsApp pada siklus I memberikan gambaran kemampuan guru di SDN 18 Bengkalis selama diberikan pemberlakuan pembelajaran dari 8 orang jumlah guru dengan hasil rata-rata yang berkategori cukup. Ini disebabkan dalam WhatsApp mereka masih kesulitan untuk menjelaskan secara panjang lebar dengan menggunakan bahasa tulis, sehingga untuk mengantisipasi digunakan rekaman akan tetapi dibatasi oleh durasi sehingga penyampaian dalam materi banyak yang kurang untuk itu dilakukan perbaikan Kembali pada siklus II dengan hasil terlihat pada tabel 3 .

Tabel 3. Kemampuan Guru dalam Pembelajaran Daring dengan Menggunakan WhatsApp Siklus II

\begin{tabular}{|c|l|c|c|c|c|c|c|c|c|}
\hline No. & Kategori & Guru & Guru & Guru & Guru & Guru & Guru & Guru & Guru \\
\hline 1 & $\begin{array}{l}\text { Guru mampu membuka } \\
\text { pembelajaran dengan } \\
\text { menggunakan WhattApp }\end{array}$ & 70 & 85 & 77 & 88 & 80 & 79 & 77 & 89 \\
\hline 2 & $\begin{array}{l}\text { Guru mampu mengirim } \\
\text { meteri yang akan } \\
\text { disampaikan melalui } \\
\text { WhatssApp }\end{array}$ & 65 & 76 & 85 & 84 & 79 & 83 & 75 & 76 \\
\hline
\end{tabular}




\begin{tabular}{|c|l|c|c|c|c|c|c|c|c|}
3 & $\begin{array}{l}\text { Guru mampu menjelaskan } \\
\text { meteri yang disampaikan } \\
\text { melalui WhatssApp }\end{array}$ & 80 & 77 & 78 & 75 & 68 & 88 & 78 & 82 \\
\hline 4 & $\begin{array}{l}\text { Guru mampu membimbing } \\
\text { diskusi di whatssApp }\end{array}$ & 65 & 80 & 86 & 69 & 73 & 76 & 89 & 75 \\
\hline 5 & $\begin{array}{l}\text { Guru mampu menutup } \\
\text { pembelajaran dengan } \\
\text { menggunakan WhattApp }\end{array}$ & 75 & 75 & 79 & 70 & 77 & 80 & 76 & 80 \\
\hline 6 & Rata-rata & 71 & 78.6 & 81 & 77.2 & 75.4 & 81.2 & 79 & 80.4 \\
\hline 7 & Kategori & B & B & SB & B & B & SB & B & B \\
\hline
\end{tabular}

Setelah selesai dilakukan perbaikan pada siklus I maka dilihat Kembali kemampuan guru dalam pembelajaran daring dengan menggunakan WhatsApp sesuai dengan tabel 3 dari 8 orang guru terlihat 2 orang yang memperoleh kategori sangat baik, dan 6 orang yang mendapatkan kategori baik. Dalam pembelajaran yang dilakukan guru dengan menggunakan WhatsApp sudah mengalami peningkatan dibandingkan pada siklus I. Guru pada siklus II ini sudah mampu menggunakan WhatsApp dalam menjelaskan, memberikan bimbingan, dan juga memberikan tugas-tugas yang akan dikerjakan guru.

\section{SIMPULAN DAN REKOMENDASI}

Simpulan penelitian ini bahwa kemampuan guru dalam menggunakan WhatsApp sebagai arternatif pembelajaran secara daring pada masa pandemic di SDN 18 Bengkalis mengalami peningkatan kemampuan guru pada siklus I dan Siklus II dengan diberikan perlakukan oleh kepada sekolah sebagai kegiatan supervise untuk menilai dan melihat peningkatan pembelajaran yang lebih efektif. Rekomendasi dalam penelitian ini adalah guru harus lebih matang lagi persiapan dalam pembelajaran daring serta harus didukung oleh orang tua murid untuk sama-sama membantu anak dalam belajar supaya lebih efektif pembelajaran yang akan sampai kepada siswa.

\section{DAFTAR PUSTAKA}

Arikunto. (2006). Prosedur Penelitian Suatu Pendekatan Praktik. Edisi Revisi. Jakarta: Rineka Cipta.
Arnesti, N., \& Hamid, A. (2015). Penggunaan Media Pembelajaran Online - Offline Dan Komunikasi Interpersonal Terhadap Hasil Belajar Bahasa Inggris. Jurnal Teknologi Informasi \& Komunikasi Dalam Pendidikan, 2(1), 12-20.

Basori, B. (2017). Efektifitas Komunikasi Pembelajaran Online Dengan Menggunakan Media E-Learning Pada Perkuliahan Body Otomotif. Jurnal Ilmiah Pendidikan Teknik Dan Kejuruan, 7(2), 39-45.

Gikas, J., \& Grant, M. M. (2013). Mobile computing devices in higher education: Student perspectives on learning with cellphones, smartphones \& social media. Internet and Higher Education.

Jumiatmoko. (2016). Whatsapp Messenger dalam Tinjauan Manfaat Dan Adab. Wahana Akademika, 3(1), 51-66.

Moore, J. L., Dickson-Deane, C., \& Galyen, K. (2011). E-Learning, online learning, and distance learning environments: Are they the same? Internet and Higher Education.

Muhammad Wildan Sahidillah, Prarasto Miftahurrisqi. (2019) WHATSAPP SEBAGAI MEDIA LITERASI DIGITAL SISWA. Varia Pendidikan. , 31 (1),52-57.

Pranajaya, \& Hendra, W. (2017). Pemanfaatan Aplikasi WhatsApp (WA) di Kalangan Pelajar (Studi kasus di MTs Al Muddatsiriyah dan MTs jakarta Pusat). 
Prosiding SNaPP2017 Sosial, Ekonomi, Dan Humaniora, 7 (1), 98-109.

Sriwihajriyah, N., Ruskan, E. L., \& Ibrahim, A. (2012). Sistem pembelajaran dengan elearning untuk persiapan ujian nasional pada SMA Pusri Palembang. Jurnal Sistem Informasi (JSI), 4(1), 450-449.

Watie, E. D. S. (2011). Komunikasi dan Media Sosial (Communications and Social Media). The Messenger, 3(1), 69-75. 